\title{
THE OLIVINE MELILITITE - KIMBERLITE ASSOCIATION OF NAMAQUALAND
}

By

Department of Geochemistry, Oñ versity of Cape Town.

In the Namaqualand-Bushmanland area of South Africa are a large number of diatremes and plugs, representing the youngest phase of volcanism on the sub-continent. They form a dense cluster about the village of Gamoep, in Bushmanland, whilst isolated but apparently related occurrences are found in the vicinity of Bitterfontein in the south ( $\left.31^{\circ} 10^{\prime} \mathrm{S} 18^{\circ} 15 \mathrm{E}\right)$, and Aggenys to the north ( $\left.29^{\circ} 10^{\prime} \mathrm{S} 18^{\circ} 5 \mathrm{OE}\right)$. These latter are separated by some $70 \mathrm{~km}$. and $40 \mathrm{~km}$. respectively from the main Gamoep cluster. The overall distribution follows a roughly NNESSW trend, over a distance of some $200 \mathrm{~km}$.

The diatremes occur on surface as slight depressions, usually accompanied by abundant calcrete. Some are filled with sediment up to depths of $800 \mathrm{ft}$. Dinosaur fossils from the sediments suggest an Upper Cretaceous age. Recovery of chrome-diopside, pyrope, garnet and ilmenite from borehole concentrates has led to the classification of these diatremes as kimberlites, although, despite extensive prospecting, they have not yielded a single diamond. Such classification is therefore debatable.

Associated with some of the sediment-filled pipes are spectacular breccia necks, composed exclusively of large block of a variety of gneisses. These postdate the sediments, which in places have been forced between the agglomerate blocks.

The volcanic plugs occur as prominent rounded hills in the same general area as the "kimberlites". They include olivine-nephelinites, olivine-nepheline-melilitites and olivine melilitites. A single radiometric date - from a pipe near Bitterfontein - yields an age of 38,5 million years. This is apparently younger than the "kimberlites", but compares closely with a value of 35,7 million years obtained for the phonolites of the Klinghardt mountains of southern South West Africa, (Kröner, 1973).

Major and trace element analyses have been carried out on these Oligocene volcanico of Namaqualand-Bushmanland and have shown significant geochemical variations across the Province.

The most northerly plug studied is markedly enriched in $\mathrm{MgO}$ ( $21 \%$ ), is highly undersaturated $\left(35,2 \% \mathrm{SiO}_{2}\right)$, and is best described as a feldspathoid-free phlogopite-perovskite picrite. It contains dunite inclusions, as do a number of other plugs in the north, and has also yielded small xenoliths of chromiferous garnet lherzolite, very similar to those found in kimberlites. Mineral analysis of one of the four phase inclusions (Hox), is given in Table 1 . The most important observations are the following:

Olivine composition is $\mathrm{Fo}_{91}$. The garnets are similar in composition 
to chromiferous kimberlite varieties, though slightly richer in Ca relative to $\mathrm{Cr}$, and poorer in $\mathrm{Mg}$. (Gurney, pers. comm.). Clinopyroxenes have a $\mathrm{Ca} / \mathrm{Ca}+\mathrm{Mg}$ ratio of 0,47 , which is slightly higher than corresponding Matsoku values $(0,45)$, but identical to values from kimberley clinopyroxenes. Using Boyd's solvus at $30 \mathrm{~kb}$ (Boyd, 1970), an equilibration temperature of $960^{\circ} \mathrm{C}$ is indicated. Orthopyroxenes have a low $\mathrm{Al}_{2} \mathrm{O}_{3}$ content $(1,21 \%)$, but higher than that found in most kimberlite garnet 1 herzolites. Gurney, Harte and Cox (this vol.), report values of $0,71-0,87$ wt. $\mathrm{Al}_{2} \mathrm{O}_{3}$ from 23 orthopyroxene analyses - 16 from Matsoku, 6 from Kimberley and 1 from the Roberts Victor pipe. The Namaqualand inclusion indicates equilibration at $38 \mathrm{~kb}$ using McGregors diagram for $\mathrm{Al}_{2} \mathrm{O}_{3}$ content of orthopyroxenes (McGregor, quoted by Boyd, 1973). As Hox is believed to be an accidental inclusion, the pressure of $38 \mathrm{~kb}$ will fix a minimum depth for origin of the lost magma at approximately $130 \mathrm{~km}$.

\section{T A B L E I}

Mineral Analysis of Hox, a Garnet Lherzolite

\begin{tabular}{|c|c|c|c|c|}
\hline & Garnet & Opx & Cpx & Olivine \\
\hline $\mathrm{MnO}$ & 0,43 & 0,12 & 0,09 & 0,10 \\
\hline $\mathrm{Na}_{2} \mathrm{O}$ & 0,01 & 0,10 & 1,52 & 0,02 \\
\hline $\mathrm{FeO}$ & 7,96 & 5,26 & 2,18 & 8,66 \\
\hline $\mathrm{SiO}_{2}$ & 41,50 & 56,50 & 54,94 & 40,65 \\
\hline $\mathrm{CaO}$ & 5,57 & 0,45 & 21,06 & 0,04 \\
\hline $\mathrm{Al}_{2} \mathrm{O}_{3}$ & 21,35 & 1,21 & 2,14 & 0,02 \\
\hline $\mathrm{TiO}_{2}$ & 0,07 & 0,03 & 0,05 & 0,02 \\
\hline MgO & 19,29 & 34,96 & 17,04 & 49,97 \\
\hline \multirow[t]{2}{*}{$\mathrm{Cr}_{2} \mathrm{O}_{3}$} & 2,53 & 0,45 & 1,66 & 0,03 \\
\hline & 99,88 & 99,09 & 100,68 & 99,52 \\
\hline
\end{tabular}

(Analysis by Dick Rickard, U.C.T.)

The Bitterfontein pipes in the south are strongly depleted in MgO and $\mathrm{Ni}$, and are even further depleted in $\mathrm{SiO}_{2}$ compared to those in the north. (MgO: 21\% to 10\%, Ni: $900 \mathrm{ppm}$ to $73 \mathrm{ppm}^{2}, \mathrm{SiO}_{2}$ : 35,2\% to 31,5\%). $\mathrm{Cr}_{2} \mathrm{O}_{3}$ is also significantly depleted to the south. $\mathrm{CaO}_{2} \mathrm{Al}_{2} \mathrm{O}_{3}, \mathrm{TiO}_{2}$, and MnO are accordingly enriched relative to the northern pipes.

Further salient geochemical features are the high concentrations of $\mathrm{TiO}_{2}, \mathrm{Na}_{2} \mathrm{O}$ and $\mathrm{K}_{2} \mathrm{O}$ throughout the Province, with rather erratic variation of the alkalis. Trace element data available to date show 
high concentrations of $\mathrm{Zn}, \mathrm{Cu}$ and $\mathrm{Ba}$.

Preliminary calculations using available major element data suggest that the rock compositions in different parts of the Province can be related by simple subtraction (or addition) of olivine, together perhaps with minor amounts of clinopyroxene, orthopyroxene, garnet and spinel.

The parent magma is believed to be derived by small amounts of partial melting in the low velocity zone (Green, 1971), possibly envolving a Ti-rich phlogopite similar to that described from Lashaine inclusions (Dawson, 1972). Such a mica could supply appreciable amounts of $\mathrm{Ba}, \mathrm{Rb}$ and $\mathrm{Sr}$ to the melt. Melting is thought to yield Ti-andK-rich fluids of olivine-nepheline composition. It is suggested that crystallization of olivine (which is richer in $\mathrm{SiO}_{2}$ than the parent melt) will result in a denser crystal mush at depth, relatively enriched in $\mathrm{SiO}_{2}$ and $\mathrm{MgO}$. Strained olivine fragments in some of the rocks are thought to represent disaggregated upper mantle material which has contaminated the crystal mush, enhancing the $\mathrm{MgO}$ and $\mathrm{SiO}_{2}$ enrichment. The remaining, lighter liquid will be depleted in MgO and $\mathrm{SiO}_{2}$ but enriched in the other oxides. The increase in $\mathrm{Al}_{2} \mathrm{O}_{3}$ and $\mathrm{CaO}$ concentrations results in crystallization of melilite-bearing assemblages on emplacement. Erratic variation of the alkalis may suggest variations in the compositions of separate source areas, but more probably reflects variable loss of volatiles during eruption.

The Middle Tertiary is not represented in South African off-shore sediments, presumably because of marginal uplift and warping of the continent. It is suggested that this caused deep seated fracturing in Namaqualand-Bushmanland, triggering off volcanic activity. Similar parent magmas were formed in different parts of the Province, but in the south, closer to the coast, upper levels of a differentiated magma column were tapped. This resulted in the most undersaturated (melilitebearing)magmas being extruded. To the north, and further in land, possibly closer to the axis of warping, deeper levels were tapped by these fractures. Extrusion of a Mg-enriched crystal mush resulted.

The Klinghardt phonolites are also of Mid-Tertiary age (Kröner, 1973). It is tentatively suggested that they are related to the Namaqualand-Bushmanland volcanics, but are derived from a more siliceous parent, which was produced by greater degrees of partial melting in the Low Velocity Zone.

The relationship between the "kimberlites" and the melilitenepheline bearing suite of volcanics remains speculative. It is possible that the sediment filled pipes are derived from the same parent magma as the Oligocene volcanics, but represent an earlier, highly fractionated and volatile enriched fraction. This fraction would then be intruded ahead of the denser and consequently younger portions. 


\section{References}

Boyd, F.R. (1970). Garnet Peridotites and the System $\mathrm{CaSiO}_{3}-\mathrm{MgSiO}_{3}-$ $\mathrm{Al}_{2} \mathrm{O}_{3}$. Min. Soc. Am. Spec. Pub. No. 3, Pp 63-75.

(1973). Pres. Address to the Geochem Soc.

Dawson J.B. (1972). Kimberlites and their Relation to the Mantle. Phil. Trans. R.S. Lond. A. 271, pp 297-312.

Green, D.H. (1971). Compositions of Basaltic Magmas as Indicators of Conditions of Origin: Application to Oceanic Volcanism. Phil. Trans. R.S. Lond. A. 268, pp 707-721.

Gurney, J.J., Harte, B., and Cox, K.G. (1973). The Composition of Mantle Xenoliths in the Matsoku Kimberlite Pipe (This Vol.).

Kröner, A. (1973). Comments on "Is the African Plate Stationary?" Nature, Vol. 243, pp 29-30. 